\title{
A Comparative Study of Refuge in Iran and Australia under Principles of Geneva Convention
}

\author{
Fahimeh Tavangar Marvasty ${ }^{1}$, Hamidreza Jamali ${ }^{2} \&$ Alireza Arashpour ${ }^{3}$ \\ ${ }^{1}$ Depatment of Law, Najafabad Branch, Islamic Azad University, Najafabad, Iran \\ ${ }^{2}$ Department of Law, Shahreza Branch, Islamic Azad University, Shareza, Iran \\ ${ }^{3}$ Department of Law, University of Isfahan, Isfahan, Iran \\ Correspondence: Hamidreza Jamali, Department of Law, Shahreza Branch, Islamic Azad University, Shareza, \\ Iran. E-mail: hamidrezajamali@yahoo.com
}

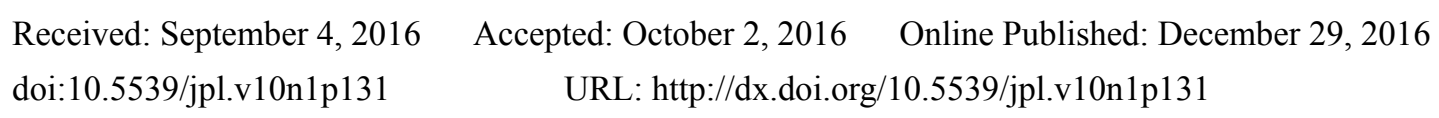

\begin{abstract}
The refuge and its rights are considered as one of the controversial categories and issues of the human rights. In this regard, the Geneva International Convention and the attached protocol can be referred as the most important international document and the most important and valuable measurement criterion related to the refugees.

In this research, the rules of Iran and Australia under the Geneva Convention and the attached protocol are compared, that the Iran and Australia's government have joined it. It seems that considering the accession of both Iran and Australia countries to the Geneva Convention, the domestic rules of these countries are perfectly conformed to this international document. Also, it seems that considering the reports of the Australia human rights commission and other defenders' authorities of human rights, the approval of the Australia new rule about prohibition of the arrival of the refugees who arrived by boat illegally on seashore of this country and transferring them to other countries, is contrary to the principle of " not returning ", that has been mentioned in the related documents.
\end{abstract}

Keywords: refuge, comparison, Iran, Australia, Geneva Convention (1951)

\section{Introduction}

Refuge issue becomes increasingly broader dimensions in the contemporary world. And the countries enact stricter rules and regulations to control and manage the refugee population, that on the one hand, these rules reflects the rights and duties of the people in that country and on the other hand, they represent the adherence of that country to the international law and human rights criteria which are relevant to refugees.

The reason for selecting Iran and Australia for comparison is that from one hand, Iran is confronted with a large number of refugees from Syria, Iraq and Afghanistan because of regional changes and from other hand, among each Australian people, at least one of them was born out of Australia or one of the parents are from a foreign country (Feller, 2008, 208). So, both countries are considered as a destination country for the asylum seekers, and despite the difference in the legal system of both countries, Iran is based on Romano-Germanic system and Australia is based on the common-law system، are proper for the comparison.

In this research, at the beginning of each definition about the refugee, refuge conditions, refugees' rights and tasks, the conventional criteria are propounded as the main and initial criterion and subsequently, domestic rules of Iran and Australia will be pointed out. Finally, the rules of both countries will be compared with the best pattern that is the conventional criteria.

The most important domestic rules of Iran pertaining to the refugee that are assessed in this research are such as: constitution (the principle of 155), refugees' regulations which was approved in 1963, the regulation of political refugee travel document which was approved in 1987, and the most important domestic law of Australia in this field is Emigration law and its subsequent reforms.

\subsection{Aim of Research}

The aim of this research is finding the similarities and differences in the rules of both countries pertaining to 
refuge and enhancing the refugees' knowledge level about their rights and tasks.

\subsection{Research Questions}

How much Iran and Australia are bounded to Geneva Convention criteria pertaining to the refugees?

Is law enactment of Australia government "based on preventing the asylum seekers' who arrive illegally by boats to this country and returning them to Malaysia and New Guinea island" violator of the mentioned criteria of convention article about the principle of " not returning" the asylum seekers ${ }^{1}$ ?

\section{Definition of Refugee}

\subsection{Under the Convention}

Geneva Convention, which is accounted as the most important international document pertaining to the refugees and it is known as the refugees' charter, has presented a comprehensive definition of refugee. Certainly, it should be noted that the convention member states, mostly act according to their benefits and national policy and they provide different interpretations about this definition (Ale Kajbaf, 2010, 206).

According to the above-mentioned convention, the term of refugee is defined as:

The refugee is applied to a person who fears justifiably of the issue because of race, religion, nationality, membership in some social groups or for having political opinion is under persecution, torment and harassment, who lives out of his/her usual place of residence and/or for the above mentioned reason, he/she is going to be under the protection of that country. Or if he/she is stateless, and lives out of his/her country of his/her permanent residence, he/she is not able or does not want to return to that country (Ibid).

\subsubsection{Exceptions}

This Convention has excluded some people from its provisions, including those that:

A) Have committed crimes against peace or war crimes (according to the recorded definitions in the international documents which has been set to predict the provisions relating to this crime).

B) Before being accepted as refugees in the country, they had committed a main crime out of the country that includes punishment.

C) Have committed the acts contrary to the purposes and principles of the United Nations

\subsection{According to the Statute Laws of Iran}

\subsubsection{Refugees' Regulations Approved by the Cabinet (1963)}

According to these regulations, the refugee is applied to a person who fears justifiably of his/her life or his/her family members' life and torment because of race, religion, nationality, membership in some social groups who refuge to Iran (Set of rules and regulation for the foreign nationals، 2006، 91).

2.2.2 Regulations of Socioeconomic and Cultural Program of the Islamic Republic of Iran Approved by the Cabinet (2005)

According to the regulation, the term of refugee is applied to a person who fears justifiably of the issue because of race, religion, nationality, membership in some social groups or for having political opinion is under torment, who lives out of his/her usual place of residence and/or for the above mentioned reason, he/she is going to be under the protection of that country. Or if he/she is stateless, and lives out of his/her country of his/her permanent residence, he/she is not able or does not want to return to that country.

\subsubsection{The Principle of the Iran Constitution:}

Refugee is not defined in this principle, but only the political refuge is pointed out. Therefore, according to the Iranian constitution, only political refuge will be accepted due to this principle (Hashemi, 2005, 262).

\subsubsection{Exceptions}

The below mentioned people are not included the above mentioned definitions of refuge, according to the Iranian statute laws.

- Traitors and criminals (the constitution principle' 155 ' of the Islamic Republic of Iran)

- People with bad intentions (refugees' regulations article '2')

\footnotetext{
${ }^{1}$ Article: Article1: any contracting governments will not banish or return the any refugee to the lands where his/her life or freedom will be a threat because of race, nationality, and membership in a special social group or having political opinions.
} 
- People who committed war crimes or the crimes against peace or humanity or severe crimes of public right (refugees' regulation article'2')

- People who committed crimes such as murder, drug trafficking, robbery, etc.

- People who committed the acts contrary to the purposes and principles of the United Nations. (Nazari Tajabadi, 1990, 35).

\subsection{According to Australian Immigration Law}

Conforming to paragraph A of article 1 of Australian immigration law, the refugee is applied to a person who fears justifiably of the issue because of race, religion, nationality, membership in some social groups or for having political opinion is under persecution, torment and harassment, who lives out of his/her usual place of residence and/or for the above mentioned reason, he/she does not want to be under the protection of that country or if he/she is stateless, and lives out of his/her permanent residence country, he/she is not able or does not want to return to that country (Bagaric et al., 2007, 249).

\subsubsection{Exceptions}

The people mentioned below are not accounted as the refugee according to the migration law.

- People who committed crimes against peace or war crimes or humanity.

- People who committed serious unpolitical crimes before arrival to Australia.

- People who committed the acts contrary to the purposes and principles of the United Nations.

- The applicant is considered as a serious hazard for Australia security

- If the applicant is convicted of a serious crime that is considered as a serious hazard for Australia society.

2.4 Definition of Refugee in Iran and Australia Laws According to Geneva Convention and Exceptions Applied in This Definition

The presented definitions of the refugee in the domestic laws of both Iran and Australia countries are fully consistent with the definition provided in the refugee Convention. Therefore, in terms of definitions, there is not any contradiction between domestic laws of both countries with international document of Geneva Convention.

The discussable points in theses definitions are the reasons for justifiable fear of persecution. According to the provided definitions of refugee, the justifiable fear of persecution should be based on one of the reasons of race, religion, membership in a special social group or having a special political opinion.

The convention does not define these reasons. Also, Iran domestic laws did not define these reasons and as it was mentioned, considering the Iranian constitution, only political refugees are actually accepted. But Australian domestic laws contrary to the Iranian domestic laws have explained and defined some concepts.

For example: two types of special social groups have been explained (Bagaric et al., 2007, 271):

1) The special social group comprises the applicant's family members.

2) Each member of the group contributes on a characteristic, but with the following terms:

2.1) This characteristic is inherent or unchangeable.

2.2) This characteristic is so fundamental for identity or conscience that cannot and should not force him to renounce it.

2.3) This characteristic distinguishes this group from the rest of society.

Finally, it should be noted that these general phrases should be explained and defined correctly in the domestic laws of the countries. About the exceptions applied in the definition of the refuge, any contradiction cannot be seen between domestic laws of both countries with an international document of the Geneva Convention.

\section{Terms of Refuge}

\subsection{According to Geneva Convention (1951)}

According to the Convention, someone with the following qualifications is considered as the refugee:

\subsubsection{Someone Who Is Living out of His/Her Country of Nationality or Habitual Residence}

Considering the mentioned definition about refuge, one term of refuge is to live out of country of nationality or habitual residence (derived from paragraph A, article 1 of the convention). According to this term, someone who 
is living in the country of nationality or in his/her habitual residence cannot be named as a refugee, even if helshe has other terms of refuge. These terms distinguish the refugees from that group that named domestic asylum seeker, because these people are living inside their country boards and are still dependent on the legal system of that country. It should be noted that "legal or illegal person's arrival to another country" cannot effect on the concept of "out of the country of residence", because the illegal arrival may not be considered as valid arrival, but even it is correct about such arrival in out of the country of origin (Ale Kajbaf, 2010, 212).

\subsubsection{Justifiable Fear of Persecution}

Another term to give refuge is justifiable fear in the applicant for refuge. This phrase has not been defined by the convention. So, the countries can provide different interpretations about this phrase.

\subsection{According to the Refuge Regulations of Iran (1342)}

In Iranian domestic laws such as refuge regulation any definition of fear has not provided. Therefore, there is not a legal criterion for assessing the justifiable fear.

\subsection{According to Australian Law}

The important point is that Australia migration law explains the criteria of justifiable fear. According to this law, a person has a justifiable fear of persecution while:

1) He/she fears of at least one of the 5 reasons due to race, religion، nationality, membership in a special social group and having political opinion.

2) There is an actual possibility that in case of return to the country of origin, the person will be persecuted for one or many mentioned reasons.

3) The actual possibility of persecution relates to all parts of his/her country.

4) Persecution includes both serious damage to a person and a systematic and discriminatory behavior toward a person (Australia migration 1958).

5) In case of impossible request for protection in his/her country of origin:

If government or other parties those who control all or big parts of that individual's country want or be able to protect that person effectively, he/she may not be known as a refugee. But permanent protection should be accessible to that person.

If protection is accessible, so the person will not fear justifiably of persecution and he/she will not considered as a refugee.

6) Behavior modification is not possible:

According to the law, if an individual is able to step reasonably to change his/her behavior in order to prevent from the actual possibility of persecution by his/her country, he/she will not fear justifiably of persecution. But this is not true if such change:

1) Is in contradiction with the characteristics that is fundamental for an individual identity or conscience; 2) To make an individual to hide an innate or unchangeable characteristic,

3) Or to make the individual to do the following acts:

3.1) To change his religious beliefs, including the denial of religion, or hiding his/her real religious beliefs or stop participating in his/her religious worship.

3.2) To hide his/her race, ethnicity, nationality or country of origin.

3.3) Changing their political views or hide their real beliefs.

3.4) To Hide physical, mental or intellectual disability

In addition to naming the diagnostic criteria for justifiable fear, the vague phrases such as those mentioned bellow that are related to these criteria are also explained in Australia Migration law.

1) Serious harm

In order to have a justifiable fear of persecution, the fear case should include serious harm to the individual. Serious injury is included but not limited to the following subjects:

- A threat for individual's life or freedom;

- Remarkable physical persecution; 
- Significant economic problems that threaten an individual's ability to continue living;

- Exclusion of acquisition of any kind that threatens a person's ability to continue living;

2) Systematic and discriminatory behavior

In order to have a justifiable fear of persecution, it should be included the systematic and discriminatory behavior.

Systemic means that the injury is not accidental or generalized, but just a person is targeted.

Discriminatory means that the annoying behavior affects a person or group members in a manner that distinguishes the person or group from society.

In other words, if an under fearing serious injury does not effect on a person or group to which he/she belongs, the person is not considered as a refugee (Bagaric et al., 2000, 297).

3) Actual possibility of persecution

Actual possibility should be presented for justifiable fear of persecution, that if an individual returns to his/her country of origin; persecution will be occurred in the predictable near future.

Actual possibility means that the fear of persecution is not far-fetched and is certain.

If there is a place in a person's country wherein one can live without justifiable fear of persecution, he/she will not be considered as a refugee, but that place should be secure and legally accessible to that person.

\subsection{Comparison of Refuge Terms in Iran and Australia, According to the Geneva Convention}

Despite the refuge terms in the statute laws of both Iran and Australia countries are fully accordance with the mentioned terms in the convention, but it is clearly visible that some ambiguities and general words such as fear of persecution have been explained perfectly in Australia laws, whereas any one of the present failures in convention text has not solved in this field in the Iranian approved refuge regulations as a domestic laws. So, the strong point of Australia migration act contrary to Iran refuge regulation is that: First, the general and ambiguous worlds such as justifiable fear have been explained. Second, the ambiguities relevant to the reason of justifiable fear have been explained clearly (Goodwin, 1996).

\section{Refugees' Rights and Tasks}

\subsection{Refugees' Rights According to Geneva Convention}

4.1.1 Indiscrimination in execution of regulations of this convention ${ }^{2}$

4.1.2 The freedom to perform religious affairs and the religious education of children ${ }^{3}$

4.1.3 Employment with wage ${ }^{4}$

4.1.4 Welfare ${ }^{5}$

About this right which has been pointed out in the convention chapter, the categories of rationing, housing, public education, public charity and social insurances should be pointed out too.

\subsubsection{Rationing ${ }^{6}$}

4.1.4.2 Housing ${ }^{7}$

\subsubsection{General Education ${ }^{8}$}

4.1.4.4 Public charity ${ }^{9}$

\subsubsection{Social insurance ${ }^{10}$}

4.1.5 Benefit from administrative assistance ${ }^{11}$

\footnotetext{
${ }^{2}$ Article (3) of refugees' convention

${ }^{3}$ Article (4) of refugees' convention

${ }^{4}$ Articles (17، 24 ،18،19) of refugees' convention

${ }^{5}$ Article (5) of refugees' convention

${ }^{6}$ Article (20) of refugees' convention

${ }^{7}$ Article (21) of refugees' convention

${ }^{8}$ Article (22) of refugees' convention

${ }^{9}$ Article (23) of refugees' convention

${ }^{10}$ Article (24) of refugees' convention
} 


\subsubsection{Freedom of movement ${ }^{12}$}

4.1.7 Freedom of travel ${ }^{13}$

4.1.8 Asset transfer ${ }^{14}$

4.1.9 Acquisition of citizenship. ${ }^{15}$

4.1.10 The principle of "Refugees' not returning". ${ }^{16}$

One of the most important refugees' rights which have been emphasized very much is the principle of refugees not returning to that country where they have been expelled or forced to leave it for various reasons. United Nations and other institutions always have supported this principle. But the refugee whose present is dangerous for country security wherein lives, or according to court vote is convicted of crimes commitment or serious crime and is diagnosed as a harmful person for the country cannot claim to use regulations mentioned in this article.

4.1.11 Right for referring to the court ${ }^{17}$

4.1.12 Right of membership ${ }^{18}$

4.1.13 Ownership right for movable properties and immovable properties ${ }^{19}$

4.1.14 Spiritual and industrial ownership right $\mathrm{t}^{20}$

\subsection{Refugees' Tasks under the Refugee Convention (1951)}

Refugees' tasks have been specified in the article (2) of convention upon which each refugee in the country is responsible for the following tasks:

1) To observe the country laws and regulations wherein resides.

2) To observe the terms relating to the public order;

Sanction for lack of observation of the above regulations has been explained in the article (32) of the convention. According to this article the contracting government can expel refugees because of national security protection and public order. ${ }^{21}$

\subsection{Refugees' Rights under Iran Laws}

4.3.1 According to the Refugees' Regulations Approved by the Cabinet (1963)

According to paragraphs A and B of article (7) of refugees' regulations, the refugees have rights, such as:

1) Health Services

2) Cultural services

3) Social service

4) Employment and the works which foreign national subjects are allowed to do them;

For employment some terms are necessary:

1: The refugees are allowed for the jobs which are permitted for the foreign national subjects in Iran.

2: Finding this matter (1) is responsibility of the permanent committee of refugees.

Therefore, the refugees can be employed in a free occupation by diagnose of the refugee committee, except those are legally restricted to internal national subjects or are in government monopoly and/or granted by the

\footnotetext{
${ }^{11}$ Article (25) of refugees' convention

${ }^{12}$ Article (26) of refugees' convention

${ }^{13}$ Article (26،27) of refugees' convention

${ }^{14}$ Article (30) of refugees' convention

${ }^{15}$ Article (34) of Refugees' convention

${ }^{16}$ Paragraph ( 1) of article (33) of refugees' convention

${ }^{17}$ Article (16) Refugees' convention

${ }^{18}$ Article (15) Refugees' convention

19 Article (13) Refugees' convention

${ }^{20}$ Article (14) Refugees' convention

${ }^{21}$ Convention article: Contracting governments will not banish or return the any refugee who are regularly living in their land, unless because of protection of the national security or public order.
} 
government to persons.

Refugees same as other foreign national subjects should receive a work permit from the Ministry of Labor and Social Affairs before beginning work.

According to the paragraph (c) of the article (122) of Iran labour law, the work permit will be issued if the booklet has been issued for him/her and in other words, his/her refuge was confirmed by the authorities and are considered as the refugees. Also, the ministries of foreign affairs and country have agreed to issue a work permit in writing for the refugee.

Validity duration of the work permit is one year that can be extended and renew depending upon the approval of the refugees' permanent committee.

5) Acquisition right of movable and immovable properties:

For the refugees like foreign national subjects, acquisition right has been considered. So, the rules relevant to the foreign national subjects should be investigated in order to study the refugees' rights in the field of acquisition right of movable and immovable properties.

\section{1: Acquisition of movable properties:}

There is not any restriction for the foreign national subjects and refugees about the acquisition of movable properties Iran laws, and they are allowed to acquire the movable properties without restriction, but about method of acquisition of properties, they will be follower of Iran laws according to the civil law.

Therefore, the refugees are allowed to acquire the movable properties provided that the properties are legitimate and authorized under Iran rules and regulations.

\section{2: Acquisition of immovable properties:}

According to the mentioned regulations, the refugees like foreign national subjects have the right to acquire the immovable properties.

About the acquisition of immovable properties by foreign national subjects and consequently the refugees the following rules are available:

1: The law of immovable properties (1931);

2: Regulation of acquisition of foreign national subjects (1963);

3: Regulation of acquisition method of immovable properties by the foreign national subjects who are resident in the Islamic Republic of Iran approved by the Cabinet (1995);

The acquisition of immovable properties by the refugees, two types of immovable properties must be distinguished:

- Acquisition of the arable immovable properties

- Acquisition of non-arable immovable properties

In case of the arable immovable properties should be referred to the law of immovable properties (1931). The article of this rule typically is referred to a dispossession of the arable land.

So, foreigners including the refugees yet have not right to the enjoyment of the arable ownership, which is among the private law, and this right is for Iranian citizens.

In the case of acquisition of non-arable immovable properties the acquisition approved article of foreign national subjects can be noted. According to this article, the foreign national subjects and subsequently the refugees are allowed to acquire a land for their housing or industry (Ghari Seyed Fatemi, 2003).

6) Right of referring to the courts (The right of investigation):

According to the regulations article, the refugees can refer to the judicial authorities for petition and adjudication. Therefore, the refugees can refer to internal courts as the claimant and if the courts refrain the judicial proceedings and the implementation of right and justice, they will be responsible internationally.

7) The freedom to choose housing:

According to the article (7) of regulation of refugees, the refugees like the foreign national subjects are somewhat free to choose housing.

8) Refugees' right to perform religious celebration and to educate it to their children:

According to the note of mentioned regulation, the refugees have right to perform religious celebration and to 
educate it to their children freely somewhat it is not contrary to the public order. In this regulation, observation of the public order is pointed out, because observation of the Iranian society interests is important for the legislator with regard to the school system of Islamic republic of Iran.

9) Obtaining citizenship:

Under refuge regulations (the article of 13):

"Granting citizenship to the refugees who observe the laws and regulations fully will be faced to the favorable opinion." Therefore, with regarding to Iran law texts, this right has been considered for the refugees that in case of observing the Iranian rules and regulations fully, they will be allowed to request for the obtaining of the Iranian citizenship. It should be noted that the terms of their obtaining are same as other foreigners.

\subsubsection{According to the Regulations of Issuing the Political Refugees' Travel Document}

According to the article of 1 and 3 and the above-mentioned regulations for political refugees' travel to outside the country, the travel document will be issued by the competent authorities. In this case, their entry and exit will be possible with travel document only from allowed borders of the country after the control by the competent authorities (Hashemi، 2005, 610).

\subsection{The Refugees' Tasks According to the Refugees' Regulations Was Approved by the Cabinet (1963)}

\subsubsection{Respecting the Iran Government Regulation and Security Protection}

According to the refugees' regulation article, the refugees should obligate to respect the government regulations in written form so long as they are resident in Iran. Sanction of act against Iran security or regulations have been mentioned in article of this regulation. According to this article, if a refugee act against Iran security or regulations, ministry of country with recommendations from the refugees' permanent committee will revoke his/her refuge certification.

\subsubsection{Prevention from Participation in the Political and Syndicate Activities}

According to refugees' regulations note, they should avoid participating in the political and syndicate activities (Ebadi, 2006, 57).

\subsection{The Refugees' Rights and Tasks According to the Australian Migration Law and Its Amendments}

To become a refuge in Australia, people need valid visa.

For the issuance of a valid visa from the Australian immigration department, first it must be investigated whether:

1: The person is resident in Australia, and his/her arrival was legal or illegal (onshore- protection).

2: the person has requested for refuge from outside of Australia.

Here, some types of the considered visas are investigated for each two classes, and then the rights and tasks of visa holders are recognized based on each class who are considered as the refugees.

Certainly, it should be noted that only the persons who have arrived illegally to Australia before August (2013) have right to request valid visa, because Australian government will prevent these people from arriving to Australia after August (2013).

If the refugees have been entered into the country legally, the Australian government will accept the application of refuge only through the granting of refuge valid visa.

Migration law and its amendments are the most important laws to study the types of refugees' visas and subsequently the refugees' rights and tasks in years (1989،1992،1993،1994،2012،2013). The most important amendments are in years 2012 and 2031) that are related to the refugees who illegally arrived by boat. The Australian government announced a statement the conducted agreement with Nuru and Malaysia. According to this agreement, the entry of the refugees into Australian territory is forbidden, and they are sent to the islands like Papua in New Guinean and Malaysia, Wherein their application for refuge is considered (Goodwin and Macdam, 2007).

\subsubsection{Types of the Visas Intended for Refugees}

\subsubsection{Onshore Visas}

This type of visa, including humanitarian and refugees' protection program that aims to provide the conditions for people who live in Australia and demand a protection visa or are refugees.

Australian provides protection visa for the people who are inside Australia and want to enjoy the protection of 
the Australian Government.

\subsubsection{Permanent Protection Visa (For the People Who Arrive Legally to Australia)}

Under Australia approved serious law, this visa is issuable only for the people who have legally arrived in Australia and are known as a refugee for one of the mentioned reasons after legal arrival.

Therefore, according to the new law of this country, issuance of this visa is impossible for people who have illegally arrived in Australia. Even these people do not have the right to request a temporary protection visa, because the Australian government does not allow these people to enter into this country according to the plan of border protection under the new law.

But the people who have illegally arrived in this country before approval of law and requested for a permanent protection visa under the previous law and this application is not finalized until December16 (2014), their application will turn into the temporary protection visa. Finally, this type of visa is for the people who have legally arrived in Australia not for illegal arrivals.

The right of Holder of this visa:

1: They have all the rights of permanent residents of Australia.

2: They can present the application of Australian citizenship after a period of time.

3: From the beginning, they can enjoy the benefit from Australian government for their citizens.

4: They have right to enjoy the public facilities, such as appropriate housing and food.

The people who are resident in Australia, but they arrived illegally (onshore).

These people can request the TPV, SHVs ${ }^{22}$.

4.5.1.3 Temporary Protection Visa (For the People Who Arrive Illegally in Australia)

4.5.1.3.1 Terms of obtaining temporary protection visas

You can get a TPV if:

1: To be entered into Australia illegally.

2: You are invited to request for TPV and submit a valid application.

3: You have been assessed as inclusion of Australia's protection obligations.

4: You are qualified for other terms such as the health check, safety, personality and identity.

4.5.1.3.2 The rights granted to holders of temporary protection visas

1: Limited residence permit: TPV allows you to stay in Australia for (3) years.

2: Work Permit: Holders of this visa are allowed to work.

3: Access to social security benefits

4: To enjoy short-term counseling to cure the damage caused by torture and trauma.

5: Australian adults' access to Australian migrant English program. ${ }^{23}$

6: The education right for children in elementary and secondary schools. So adults do not have the right to study at university.

7: Possibility of travel to out of Australia.

4.5.1.4 Safe haven enterprise visa.

This type of visa is for people who illegally arrive in Australia, and intend to work or study there.

The important point is that people cannot apply for a SHV and TVP together and in case of provide, just application of SHV will be considered.

The right to appeal in case of rejection of refugee visa:

If the criteria are not met for these two types of visa, application of TPV and SHVs will be refused and the

\footnotetext{
${ }^{1}$ Internal onshore in the seashore areas is a term which is propounded for Australia migration law about classification of the visas those are requested by the applicants inside Australia.

${ }^{2}$ Australia Migration English Program; this program is established by migration department in order to assist the refugee to learn English that is managed voluntarily by the people and is free.
} 
reasons for the rejection will be explained by a letter.

It should be noted that if an individual is not liable for Australia protection obligations and has not another visa, he/she have not right to resident in Australia and must return to his/her country or another safe permitted country. It should be noted that if an individual is not liable for Australia protection obligations and has not another visa, he/she have not right to resident in Australia and must return to his/her country or another safe permitted country.

\section{The Right of Review against Rejected Refuge Visas}

\subsection{Refugee Review tribunal (RRT)}

The review tribunal is an independent board that has the power and authority to review the decisions that are related to the protection visas.

Investigation is substantial rather than figural in this board. This board investigates the applicants' claims under the terms recorded in the convention relating to the refugees and a meeting is held with the participation of both parties of refugee and migration department officer.

The decisions of this board may be the initial verification from migration department means that it does not know the applicant eligible for a protection visa. Or these decisions may be the rejection of the initial decision of migration department that in this case, the file is returned to the migration department again to be reviewed, thus the migration department has to consider all guidelines and instructions of the refugee review tribunal. This board also has the right to make decision instead of the migration department. There is possibility to present the new reasons in this board.

The applicant has to submit his/her application of review to the same department during (28) days after announcing the result, which the department would send it to the mentioned board.

\subsection{Judicial Review under the Immigration Act Amendment (1994)}

The second reference is intended to appeal, certainly if the refugee review tribunal (RRT) confirms the opinion of the migration department, the review will be done through judicial procedure.

Certainly, it should be noted that the procedure is merely figural at this stage and the new reasons and new claims are not accepted here.

\subsection{Ministerial Intervention}

The visa applicant's last achievement is his/her request from the Australia minister of migration and Citizenship.

The relevant minister has the power to grant a visa to an applicant referring to Australia migration approved law article, it means that is the applicants did not success to change the idea of migration department through the refugee review tribunal and the judicial review tribunal, they can request for a visa directly from the minister.

This power which was granted to the minister is propounded as public interest powers 1. Finally, if the applicant of various visas does not receive a visa, he/she has to leave Australia.

A separate approval must be taken for every travel. If they travel without recorded approval, temporary protection visa will be canceled. ${ }^{24}$

\section{Duties of Holders of Temporary Protection Visas}

- The holder cannot apply for migration visa via humanitarian or family migration programs for family members.

- Announcing the migration department in the event of change of address.

- The holder cannot apply for another visa except TPV and SHV.

- The holder should apply for another protection visa or SHV before expire of the first visa.

\section{Special Humanitarian Visa (SHV)}

As mentioned before, SHV visa is one of the other types of visa can be requested by the people who illegally have arrived to Australia. Certainly, this type of visa same as the previous visa is only for the people who have arrived illegally to Australia before approval of the new rule, because the illegal arrival is prevented after approval of the new rule.

\subsection{Conditions for Granting SHV}

${ }^{24}$ To receive the confirmation letter, the applicants must fulfill the form titled as the application for confirmation of travel under conditions. 
SHV will be granted if:

- Arrived in Australia illegally.

- The applicant is invited to apply for a SHV and provide a valid application.

- Work application and study application should be announced by the applicant or a family member.

- Having other condition, such as investigations of health, safety, the personality and identity.

\subsection{Rights of SHV Holders}

All mentioned rights was for holders of temporary protection visa same, work permit, access to social security, enjoyment of short-term counseling to reduce the damage caused by torture and trauma, adult access to Australia migrant's English program, the education right for primary and secondary school children, the opportunity to travel outside of Australia with special approval for this type of visa holders are also assumed. And the most important right is the right of appeal in case of the applicant's visa is rejected.

One advantage of the SHPV compared to TPV is that people have a special right ${ }^{25}$ after half year from receiving the SHV, the people can apply other types of onshore visas in Australia.

\subsection{Duties of SHV Holders}

It is like the TPV holders. It is avoided from mentioning again.

\section{Offshore Visas}

This program is for settlement of the people who need humanitarian assistances from Australia country, and it is in a case that there is not any solution for them except settlement in Australia.

This program includes 2 visa category:

\section{1: Refugee category.}

2: Specific humanitarian program category.

The remarkable point is that the number of applicants who have requested to settle is much higher than the number of the available visas.

The first category of refuge visas is for the people who are under prosecution in their country and typically are living out of their country and need to be settled very much.

\subsection{Refugee Visa}

This type of visa is for people who live outside Australia and outside of their country and are under prosecution. To settle in Australia under this visa you must be introduced to the Australian government by UN High Commissioner. The visa is a permanent visa.

8.1.1 The Rights Granted to the Holders of This Visa

1: The right to study in Australia.

2: The right to work during studying in Australia.

3: The right to use Medicare and health care services provided by the Australian government.

4: Apply for Australian citizenship after 5 years of staying in Australia.

5: The possibility of applying for an Australia permanent resident visa for family members of the visa holder.

6: Participation in the free English class.

7: The right to travel outside of Australia with having the desired approval.

In the case of this type of visa like the previous case, the person should be outside of Australia while requesting and granting a visa.

8: Lack of need to pay for requesting this type of visa and Australian government accept the travel costs and other costs related to the medical tests before entering this country.

\subsubsection{Duties of the Holders of This Visa}

In the application of the applicant, he/she may also request these types of visa for his/her family members. The

\footnotetext{
${ }^{25}$ If another type of visa is requested, SHV will be expired before making decision about application of visa, whereas the application is under study, a bridging visa is given to the applicant.
} 
holders are responsible for the following tasks:

1: They must enter to into Australia during the determined date on the visa not sooner and not later.

2: They must observe all conditions relevant to the laws of Australia about this visa.

3: With the granted visa, the holders are allowed to enter into Australia only once not more.

4: Medical tests ${ }^{26}$ by a medical board related to the migration before arrival to Australia. These tests include: pregnancy, epidemic diseases, infectious diseases, necessary vaccines, etc.

5: Submission of the proof documents of family relationship if the holders' family members are included in the application.

6: Submission of identification documents which is granted by country in which one lives.

The persons who are qualified to offer this type of refuge protection visas to Australian government: (the 5 types of protection visa, special humanitarian visa program in the country, global special humanitarian visa program, the emergency rescue visa, and visa for the women at risk.)

1: An Australian citizen:

2: A person who has a permit for permanent residence in Australia;

3: A qualified citizen of New Zealand;

4: An Australian organization;

5: United Nations Commissar;

6: One of the family members: is a member of a family has a visa among the mentioned visas, he/she can offer the mentioned visa for one of his family members.

\subsection{In-country Special Humanitarian Program Visa}

This visa has been intended for the persons who are under prosecution by their country and at the same time live in their country and are not allowed to leave their country and arrive to another country as the refugee. This is a permanent visa.

\subsubsection{The Rights of Holders}

The holders of this visa are like the holders of protection visas.

IOM grants a without interest loan includes the travel cost percentage of protection visa holders and their family, and provides other services such as free consultation before and after travel. ${ }^{27}$

\subsubsection{The tasks of the Holders of this visa:}

The tasks of the holders of this visa are same as the holders of protection visa that we avoid repeating it.

\subsection{Global Special Humanitarian Program Visa}

This type of visa is a permanent visa. This type of visa is intended for people who are not refugees, but are under significant discrimination and under abuse of human rights in their country. The applicants of this visa should be offered by an Australian citizen or a person with an Australia permanent resident visa and is elder than 18 and a New Zealand citizen or the relevant organization. The rights granted to holders of this visa and their related tasks are like the previous ones.

\subsection{Emergency Rescue Visa}

This visa is intended for the people who are under persecution in their country and receiving visa is impossible through the normal process, because their life is under threat. So, their application must be dealt with exceptionally. In this case also, it is possible to introduce the person to the Australian government through the UN High Commissar. The rights and tasks of the holders of this visa are same as the holders of refuge visa.

\subsection{Women at Risk Visa}

This type of visa is intended for the women and their relatives who are under persecution in their country, and are living out of their country, and at the same time they are resident out of Australia. These women do not enjoy from any support of their female relatives, are at some risks such as death and molester, rudeness and serious

\footnotetext{
${ }^{26}$ Heath tests during travel

${ }^{27}$ Visit: intentional organization or migration IOM.

mail: trvl.lon.nrr@iom.int
} 
abuse. Priority is granted to the women at risk who are introduced by UN refugee high commissar. This visa is considered as a permanent visa.

In the year 2010,13/4 percentage of the total refuge visas were assigned to this type of visa that this number was 12/2 Percent in 2009 (Australian human rights commission, 2011, 45).

All the rights and tasks are mentioned for the holders of in-country special humanitarian visa, and global special humanitarian visa is also applied to the holders of this visa.

\section{Conclusion}

In this study, the issue of refuge under domestic laws of Iran and Australia in accordance with the Geneva International Convention relating to the refugee status and its additional protocol was investigated. Here it is beneficial to explain briefly the similarities and differences between domestic legislation of Iran and Australia relating to refuge in accordance with the best standard that is the Convention criteria.

\subsection{Similar Aspects}

\subsubsection{Definition of a Refugee and Exceptions Applied on It}

The laws of both countries have presented the same definitions according to the definition of the Geneva Convention.

\subsubsection{Reasons for Refuge}

The laws of both countries have presented the reasons for refuge such as race, religion, nationality, membership in a special social group and having a political opinion in accordance with the Convention criteria.

\subsubsection{Terms of Refuge}

The 2 required primary terms for achievement of the refuge situation have been explained in the laws of both countries under the conventional criteria (1: outside of the belonged country or usual residence, 2: presence of fear with regard to the above mentioned reasons).

\subsubsection{The Possibility of Granting Citizenship}

Under Iranian refugee regulation article, the refugee will be able to request citizenship. This is mentioned according to the type of visa and duration which must be passed after receiving visa in the Australian migration visa act. So both countries accept this right for refugees.

\subsubsection{Rights Granted to Refugees}

The laws of both legal countries such as residential permits, right of study, right of referring to the courts, ownership rights, etc. have been intended for the refugees under provisions of the convention. But it should be noted that each country applies some restrictions in granting these rights to the refugees in order to protect its security and its internal benefits.

\subsection{Distinctive Aspects}

\subsubsection{Explaining the Reasons for Refuge}

Despite the similarity of reasons for refuge under internal laws of both countries, but Australia migration law has explained clearly some reasons such as membership in a special social group, whereas the internal laws of Iran are without such an obvious explanation.

\subsubsection{Definition of Justifiable Fear}

This general phrase (justifiable fear) by which different concepts can be provided has been presented in Australia migration law, whereas Iranian laws are without such definition of the above phrase.

\subsubsection{Coding and Classification of the Refuge Laws}

One of the clear aspects of Iran and Australia internal laws is the type of legislation in the exact world, is shape of classification of laws. Australia migration law has presented the proper and true divisions. On the other worlds, different visas have been considered in this law in terms of requesting an onshore visa from inside Australia and/or outside of this country and/or in terms of gender or in terms of different conditions. Whereas, only the political refuge has been intended under the provision of Iran, indeed, is not same as Australia extent and solidarity of laws.

\subsubsection{The Right to Request Review in Case of Refuge Request Rejection}

Under Australian migration law, if the applicant's refuge application is refused by migration officer, as a 
representative of the minister of Australia migration and Citizenship affairs, it is possible for an applicant to request review from the relevant officer's decision. A refugee review tribunal and the minister's interference has been intended for this purpose under article of immigration judicial review and judicial review. Whereas in refuge regulation and in Iranian other laws, if the refuge application is refused in the refugee permanent committee, any right to request review has not been intended for the applicant and it is considered as a weak point of Iranian domestic laws.

Finally, the question must be replied that was posed in the introduction and one of the most controversial issues in the human rights meeting:

Question: Is law approval of Australia parliament (preventing to enter asylum seekers who arrive illegally by boats and setting regional agreements with Malaysia ${ }^{28}$ and New Guinea islands, (Nero Nuru and Manus)) according to the conventional criteria (paragraph 1 of article 33 " and refugee not-returning" principle)?

Whereas the authorities of Australia government know necessary to approve this law in order to protect the political and economical interests of this country, the human rights defenders, especially the Australian human rights committee knows this act of the Australia government perfectly against the refugee convention criteria.

According to the latest legislation even if the application for refuge is accepted, the applicants are not allowed to arrive to Australia and only have right to resident in the residences determined by Australia government in the mentioned Islands, that this action is far from human rights criteria.

\section{References}

Ale Kjabaf, H. (2010). The necessities of the private international law (1st ed.). Jungle Pub.

Australian human rights commission. (2011). Refugee and asylum seeker issues in Australia.

Australian migration law. (1958).

Bagaric, M., Vrachnas, J., \& Boyd, K. (2007). Dimopoilos, Penny, Migration and refugee law (cases and commentary). Cambridge university press, Sydney.

Ebadi, S. (2006). Refugees' rights. Tehran, Ganje Danesh library.

Feller, E. (2008, October 8). Fifty-ninth session of the Eecutive Committee of the High Commissioner's Programme, Agenda item 5(a): Statement by Ms. Erika Feller, Assistant High Commissioner-Protect. Geneva: UNHCR.

Geneva International Convention (1951) and its attached Protocol (1967).

Ghari Seyed Fatemi, S. M. (2003). Human rights in contemporary world (1st ed.). Tehran.

Goodwin, G. (1996). The refugee in international law (2nd ed.). Oxford Clarendon press.

Goodwin, G., \& Mcadam, J. (2007). The refugee in international law (2nd ed.). Oxford university press.

Hashemi, S. M. (2005, Autumn). Human rights and fundamental freedoms (1st ed.). Mizan Pub.

Nazari Tajabadi, H. (1990). Studying the various legal aspects of refuge issue (1st ed.). Political and International Studies office of foreign ministry.

Refugee regulations of Iran 1963.

Set of rules and regulation for the foreign nationals, 2006.

\section{Copyrights}

Copyright for this article is retained by the author(s), with first publication rights granted to the journal.

This is an open-access article distributed under the terms and conditions of the Creative Commons Attribution license (http://creativecommons.org/licenses/by/4.0/).

\footnotetext{
${ }^{28}$ The reason for selecting Malaysia is that this country has not attached to the convention. Therefore, they can turn back the applicants to their country.
} 